\title{
In vitro studies of lymphangioleiomyomatosis
}

\author{
J.L. Black*,\#, Q. Ge*,\#, S. Boustany*, , P.R.A. Johnson*,\#, M.H. Poniris*, \\ A.R. Glanville", B.G.G. Oliver*, L.M. Moir*," and J.K. Burgess ${ }^{\star}{ }^{\star *}$
}

ABSTRACT: Lymphangioleiomyomatosis (LAM) is associated with abnormal airway smooth muscle that leads to the characteristic pathology of lung nodule formation and destruction of lung tissue. The current authors have previously identified abnormal behaviour of airway smooth muscle cells from patients with asthma.

In this study, cells and tissue sections derived from patients with LAM $(n=7)$, asthma $(n=8)$, and nonasthmatic controls $(n=9)$ were compared. The presence of the antigen human melanosome (HM)B-45 was investigated, along with the proliferation and release of extracellular matrix proteins, release of endogenous prostaglandin $E_{2}\left(P G E_{2}\right)$, vascular endothelial growth factor and connective tissue growth factor, and the expression of integrins.

Positive HMB-45 staining was found in all LAM patients and no controls. Proliferation of LAM cells was not different from control cells nor was its inhibition by $\beta$-agonists, corticosteroids, rapamycin or $\mathrm{PGE}_{2}$. However, endogenous $\mathrm{PGE}_{2}$ levels were markedly decreased in LAM cells, and this was associated with decreased expression of the inducible form of cyclooxygenase (COX-2). The increased levels of connective tissue growth factor seen in asthma cells were not observed in LAM. Elastin mRNA in response to transforming growth factor- $\beta$ stimulation was markedly lower in LAM cells than either asthma or control cells.

In conclusion, lymphangioleiomyomatosis cells exhibit abnormal properties in vitro that may contribute to pathophysiology and symptomatology in patients with lymphangioleiomyomatosis.

KEYWORDS: Airway smooth muscle, asthma, lymphangioleiomyomatosis, matrix proteins

ymphangioleiomyomatosis (LAM) is a rare lung disease that affects only females, usually in their thirties, and for which the prognosis is generally extremely poor. Until recently, it was thought that survival rates postdiagnosis were $\sim 10$ yrs, but this has been revised and current estimates are closer to $15 \mathrm{yrs}$ [1]. Although the pathogenesis remains unclear, an association with tuberous sclerosis (TSC) is largely accepted $(39 \%$ of TSC patients have LAM) [2]; however, this is not universal. The LAM cell is thought to be a form of smooth muscle that is abnormally proliferative and underlies the formation of characteristic LAM nodules in the lung and angiolipomas in the kidney. The pulmonary nodules are responsible for cystic destruction of the lung, recurrent pneumothoraces and a steady decline in pulmonary function. There is some debate as to whether the abnormal smooth muscle cell arises in the airway or the vasculature and some have suggested that it may be a result of a distant metastasis [3]. The LAM smooth muscle cell is heterogeneous and LAM cells may differ in their degree of differentiation. This has hampered identification of the properties of LAM cells. The abnormal proliferation is thought to result from an aberrant form of the TSC2 gene, which leads to abnormalities in the p70S6 kinase and S6 kinase signal transduction pathways [4]. The cellular characteristics of LAM are varied, with reports of positive staining for human melanosome (HM)B-45, a melanoma antigen [5], abnormal fibroblast growth factor receptor expression [6], increased transforming growth factor- $\beta$ (TGF$\beta$ ) levels [7], abnormal nuclear expression of oestrogen receptors [8] and upregulation of some matrix metalloproteinases [9]. Thus, there is increasing evidence that the smooth muscle cells in pulmonary LAM lesions are abnormal.

Recently, it has become apparent that the airway smooth muscle cell is abnormal in asthma. Airway smooth muscle cells derived from volunteers with asthma exhibit altered behaviour, in that they proliferate more rapidly than their nonasthmatic counterparts [10], produce more connective tissue growth factor (CTGF) in response to stimulation with TGF- $\beta$ [11], produce
AFFILIATIONS

*Dept of Pharmacology, and

"Woolcock Institute of Medical Research, University of Sydney, and Transplant Unit, St Vincents Hospital Darlinghurst, Sydney, Australia.

CORRESPONDENCE

J.L. Black

Dept of Pharmacology

University of Sydney

NSW 2006

Australia

Fax: 61290365126

E-mail: judblack@med.usyd.edu.au

Received:

February 142005

Accepted after revision:

May 152005

\section{SUPPORT STATEMENT}

This study was supported by the LAM Foundation of Australia and by the National Health and Medical Research Council. 
lower levels of prostaglandin $\mathrm{E}_{2}\left(\mathrm{PGE}_{2}\right)$ [12] and their growth is not inhibited by corticosteroids, a property that is related to the absence of the transcription factor CCAAT/enhancer binding protein- $\alpha$ [13]. In addition, the extracellular matrix (ECM) proteins secreted by asthma-derived airway smooth muscle (ASM) are different from those released from control cells [14].

In the current study, the properties of smooth muscle cells derived from lungs explanted from patients with LAM, with respect to proliferation rate and the effect of corticosteroids, $\beta$ agonists, rapamycin and $\mathrm{PGE}_{2}$ on proliferation, as well as the release of CTGF, fibronectin, collagen, $\mathrm{PGE}_{2}$, vascular endothelial growth factor (VEGF) and elastin, were examined. In addition, immunohistochemical studies were conducted, in which the presence of positive staining for HMB-45 in LAM cells and the effect of incubation of segments of LAM lung tissue with TGF- $\beta$ on the expression of VEGF, CTGF and elastin were assessed.

\section{MATERIALS AND METHODS}

Lung tissue was obtained from patients undergoing resection for isolated primary lung lesions or transplantation, or, in the case of asthmatic patients, deep endobronchial biopsy. Ethical approval for the studies was obtained from the Central Sydney Area Health Service and from the University of Sydney and all patients gave written, informed consent.

Where possible, in each set of experiments, comparisons were made between asthmatic, LAM and control cells. In some experiments, only LAM and control cells were studied.

\section{Cell culture}

ASM cells were obtained from nine nonasthmatic, eight asthmatic and seven LAM patients by methods adapted from those previously described [10-13]. Briefly, with the aid of a dissecting microscope, segments of bronchi or biopsies were stripped of epithelium, thereby exposing underlying bands of smooth muscle. These were removed, placed into $12.5 \mathrm{~cm}^{2}$ tissue flasks with $10 \%$ FBS and the smooth muscle cells grew out to confluence. The characteristics of the patients are listed in table 1. ASM cells were identified by immunofluorescence to $\alpha$-smooth muscle actin and calponin and morphology under light microscopy, as previously described [10, 11]. All experiments were performed with cells that had been passaged from four to eight times.

\section{Immunohistochemical studies}

For estimation of HMB-45 staining, cells from each patient were grown on coverslips in 5\% FBS Dulbecco's phosphate buffered saline (DMEM) for 7 days and then fixed in $4 \%(\mathrm{w} / \mathrm{v})$ paraformaldehyde (seven LAM patients and three nonasthmatic controls). Mouse anti-human HMB-45 (Dakocytomation, Carpinteria, CA, USA) was added to the cells at $4 \mu \mathrm{g} \cdot \mathrm{mL}^{-1}$ for $1 \mathrm{~h}$ at room temperature. Mouse immunoglobulin $(\mathrm{Ig}) \mathrm{G}_{1}$ (5 $\mu \mathrm{g} \cdot \mathrm{mL}^{-1}$; R\&D systems, Minneapolis, MN, USA) was used as an isotype control. Cells were then washed twice in PBS and the secondary antibody, horse anti-mouse texas red $\left(15 \mu \mathrm{g} \cdot \mathrm{mL}^{-1}\right.$; Vector laboratories, Burlingame, CA, USA) was added for $30 \mathrm{~min}$ at room temperature. HMB-45-positive cells were counted by six independent observers blinded to diagnosis. Cells were scored as: no staining for HMB-45; +: $<50 \%$ of cells positive for HMB- $45 ;++$ : $\geqslant 50 \%$ of cells positive for HMB-45; and +++: $\geqslant 80 \%$ of cells positive for HMB-45. Three separate images per patient were scored and the values averaged across the six independent observers.

\section{Proliferation assay}

Incorporation of $\left[{ }^{3} \mathrm{H}\right]$-thymidine was measured following standard protocols. Cells were grown for 7 days in 5\% FBS, equilibrated in $0.1 \%$ FBS for $24 \mathrm{~h}$ and then stimulated with $5 \%$ FBS for $24 \mathrm{~h}$ and $5 \mu \mathrm{Ci} \cdot \mathrm{mL}^{-1}$ of $\left[{ }^{3} \mathrm{H}\right]$-thymidine was added during the last $5 \mathrm{~h}$ of cell culture. Thymidine incorporation was determined by liquid scintillation, counting in triplicates. The corticosteroids budesonide and fluticasone $\left(10^{-10}, 10^{-9}\right.$ and $\left.10^{-8} \mathrm{M}\right)$, the long-acting $\beta$-agonists salmeterol and formoterol $\left(10^{-10}, 10^{-9}\right.$ and $\left.10^{-8} \mathrm{M}\right), \operatorname{PGE}_{2}\left(10^{-8}, 10^{-7}\right.$ and $\left.10^{-6} \mathrm{M}\right)$ and rapamycin $\left(2 \times 10^{-9}\right.$ and $\left.10^{-8} \mathrm{M}\right)$ were added at the time of stimulation; $\geqslant 80 \%$ of cells were positive for HMB- 45 .

\section{$P E_{2}$ and VEGF release}

$\mathrm{PGE}_{2}$ and VEGF release were measured using the ELISA technique. Cells were grown for 7 days in 5\% FBS, equilibrated in $0.1 \%$ FBS for $24 \mathrm{~h}$ and then stimulated with 5\% FBS. Supernatants were collected 24, 48, 72 and $96 \mathrm{~h}$ later and assayed using ELISA kits according to the manufacturers' instructions (Cayman Chemicals, Ann Arbor, MI, USA; and R\&D Systems).

\section{Generation and isolation of mRNA for COX-2, CTGF and elastin}

ASM cells were seeded as described previously [11], in six-well plates at $1 \times 10^{4}$ cells $\cdot \mathrm{cm}^{-2}$ in 5\% FBS DMEM for $24 \mathrm{~h}$, before being synchronised for $24 \mathrm{~h}$ in $0.1 \%$ insulin, transferrin, selenium (ITS) in DMEM. For the induction of cyclooxygenase2 (COX-2) mRNA, cells were then incubated in ITS or 5\% FBS for a period ranging from $15 \mathrm{~min}$ to $24 \mathrm{~h}$. For stimulation of CTGF and elastin mRNA, TGF- $\beta\left(1 \mathrm{ng} \cdot \mathrm{mL}^{-1}\right)$ was added to the cells for 4-24 h. At the completion of each incubation period, cells were washed in PBS and kept on ice, lysed and stored at $-20^{\circ} \mathrm{C}$ until extraction. Total RNA was extracted from the cells using a Macherey-Nagel Nucleospin RNA II kit, according to the manufacturer's instructions. Following extraction, samples were eluted in $40 \mu \mathrm{L}$ RNase-free water and stored at $-20^{\circ} \mathrm{C}$ until use.

A two-step PCR for COX-2 was performed on RNA from each patient. Reverse transcription was carried out upon $5 \mu \mathrm{L}$ of total RNA using a RevertAid H Minus M-MuLV Reverse Transcriptase kit (MBI Fermentas, Hanover, MD, USA) as per the manufacturer's instructions. PCR was then carried out ( $2 \mu \mathrm{L}$ cDNA) using a BioTaq Red DNA polymerase kit (Bioline Australia, Alexandria, Australia). PCR was also carried out for $18 \mathrm{~S}$ ribosomal RNA to allow for the amounts of COX-2 mRNA detected to be standardised. COX-2 primers $(0.5 \mu \mathrm{M})$ used were as follows: forward primer $5^{\prime}-$ ATGAGATTGTGGGAAAATTGCT-3' and reverse primer $5^{\prime}$ GATCATCTCTGCCTGAGTATC-3'. The $18 \mathrm{~S}$ primers $(0.25 \mu \mathrm{M})$ used were as follows: forward primer $5^{\prime}$ CTCAACACGGGAAACCTCAC-3' and reverse primer 5'-GACAAATCGCTCCACCAACT-3'. All the reactions commenced with initial denaturation of $94^{\circ} \mathrm{C}$ for $1 \mathrm{~min}$, followed by 27 cycles of denaturation at $94^{\circ} \mathrm{C}$ for $15 \mathrm{~s}$, annealing at $55^{\circ} \mathrm{C}$ for $30 \mathrm{~s}$ and extension at $72^{\circ} \mathrm{C}$ for $30 \mathrm{~s}$ for $\mathrm{COX}-2$, and 12 cycles 


\section{TABLE 1 Characteristics of study patients}

\begin{tabular}{|c|c|c|c|c|}
\hline 1 & 29 & $\mathrm{~F}$ & Asthma & Endobronchial biopsy \\
\hline 3 & 25 & M & Asthma & Endobronchial biopsy \\
\hline 4 & 21 & M & Asthma & Endobronchial biopsy \\
\hline 5 & 23 & M & Asthma & Endobronchial biopsy \\
\hline 8 & 20 & M & Asthma & Endobronchial biopsy \\
\hline 9 & 21 & $\mathrm{~F}$ & Eisenmenger's & Explanted lungs \\
\hline 10 & 38 & $F$ & Primary pulmonary hypertension & Explanted lungs \\
\hline 11 & NK & NK & NK & Donor \\
\hline 12 & 18 & M & Respiratory failure & Explanted lungs \\
\hline 17 & 31 & NK & Tetralogy of Fallot & Explanted lungs \\
\hline 18 & 56 & $\mathrm{~F}$ & LAM & Explanted lungs \\
\hline 19 & 39 & $\mathrm{~F}$ & LAM & Explanted lungs \\
\hline 20 & 48 & $\mathrm{~F}$ & LAM & Explanted lungs \\
\hline 21 & 55 & $\mathrm{~F}$ & LAM & Explanted lungs \\
\hline 22 & 46 & $\mathrm{~F}$ & LAM & Explanted lungs \\
\hline 23 & 39 & $\mathrm{~F}$ & LAM & Explanted lungs \\
\hline 24 & 34 & $\mathrm{~F}$ & LAM & Explanted lungs \\
\hline
\end{tabular}

F: female; M: male; NK: not known; LAM: lymphangioleiomyomatosis.

of denaturation at $94^{\circ} \mathrm{C}$ for $30 \mathrm{~s}$, annealing at $56^{\circ} \mathrm{C}$ for $30 \mathrm{~s}$ and extension at $72^{\circ} \mathrm{C}$ for $30 \mathrm{~s}$ for $18 \mathrm{~S}$. For all reactions, a final extension at $72^{\circ} \mathrm{C}$ for 5 min was performed. Reaction products were separated on $10 \%$ TAE polyacrylamide gels by electrophoresis and stained with $0.2 \%$ silver nitrate solution.

\section{Real-time RT-PCR}

RT-PCR was performed for the detection of CTGF mRNA, as described previously [11] (CTGF forward primer $\left(5^{\prime}\right.$-TGTGTGACGAGCCCAAGGA-3'), reverse primer $\left(5^{\prime}\right.$ TCTGGGCCAAACGTGTCTTC-3') and internal probe (FAM5'-TGGTTGGGCCTGCCCTCGC-3'-TAMRA)) using the TaqMan One-Step RT-PCR Master Mix Reagents Kit (PE Applied Biosystems, Foster City, CA, USA). Elastin mRNA detection was performed using the TaqMan Gene Expression Assay (Hs00355783_m1, PE Applied Biosystems). For precise quantitative analysis of gene expression, the pre-developed TaqMan assay reagents (Endogenous Control Ribosomal RNA Control (18S rRNA); PE Applied Biosystems) were included in the RT-PCR reactions $(0.2 \times$ concentration for CTGF and elastin). Negative controls were included in every real-time RT-PCR.

\section{Extracellular matrix protein release}

ELISAs for fibronectin, collagen I and IV, versican, perlecan, chondroitin sulfate, thrombospondin were carried out as previously described [14].

\section{Flow cytometry}

ASM cell surface integrin expression was studied using flow cytometry. Cells in culture, seeded at $1 \times 10^{4} \mathrm{cells} \cdot \mathrm{cm}^{-2}$ and grown in DMEM containing 5\% FBS for 7 days, were trypsinised (0.02\% trypsin-0.02\% EDTA) and washed twice in PBS containing $0.1 \%$ BSA. Following centrifugation, cells were resuspended $\left(1 \times 10^{5}\right.$ cells $\cdot$ tube $\left.^{-1}\right)$ in PBS containing $1 \%$ BSA for $30 \mathrm{~min}$ to prevent nonspecific antibody binding. Cells were then incubated with anti-human integrin subunit monoclonal antibodies (in PBS/0.1\% BSA) directed against $\beta_{1}, \alpha_{1} \alpha_{2}, \alpha_{4}, \alpha_{5}$, $\alpha \mathrm{V}$ (Chemicon (anti- $\alpha_{2}$-fluorescein isothiocyanate (FITC), anti$\alpha_{5}$-FITC, anti- $\alpha_{4}$-phycoerythrin (PE), anti- $\alpha \mathrm{V}-\mathrm{PE}$ conjugated)) or IgG (R\&D systems) control for $30 \mathrm{~min}$ at room temperature. Cells were then washed with PBS/0.1\% BSA. Unconjugated antibodies $\left(\beta_{1}, \alpha_{1}\right.$ and $\left.\operatorname{IgG}\right)$ were then incubated for a further 15 min with either R-PE- or FITC-conjugated goat anti-mouse secondary antibody. Cells were then fixed in $4 \%$ formal saline and analysed using a FACScan flow cytometer (Becton Dickinson).

\section{RESULTS}

HMB-45 staining was positive in all seven LAM patients (fig. 1a) and none of the three nonasthmatic controls (fig. 1c) studied. Positive staining was estimated as $>50 \%$ of cells in all LAM patients and in one patient $>80 \%$. HMB- 45 staining was also apparent in muscle bundles in sections of bronchus from LAM patients (fig. 1e) and in areas of parenchyma (fig. 1h). 

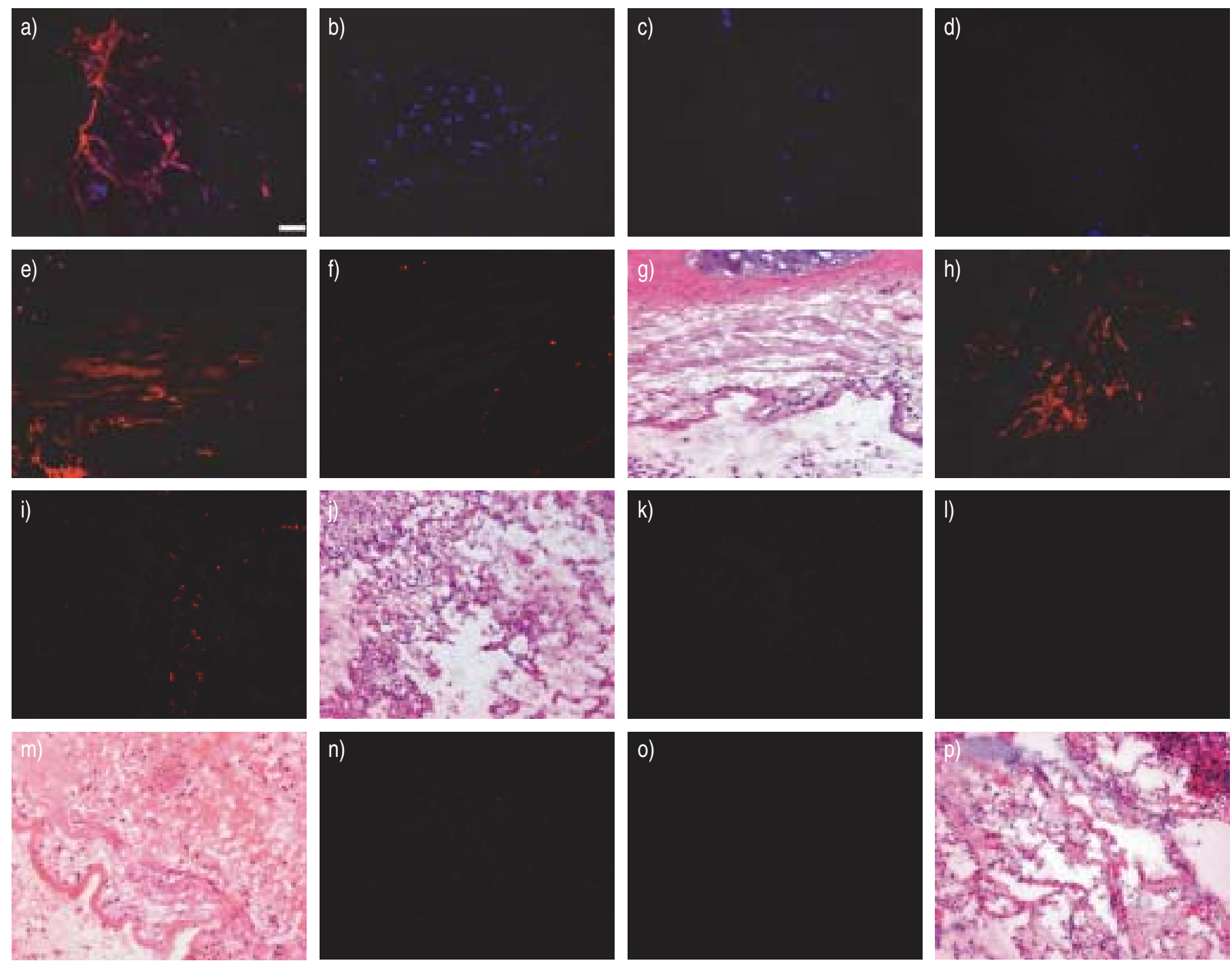

FIGURE 1. Human melanosome (HM)B-45 positive staining shown in red in smooth muscle cells derived from a lymphangioleiomyomatosis (LAM) patient (a). Control cells from which the primary antibody has been omitted are shown in b) and cells from a non-LAM patient with control cells are shown in c) and d), respectively. HMB-45positive staining in a smooth muscle bundle of a section of LAM lung and in lung parenchyma are seen in e) and h) with the control staining in f) and i). Non-LAM sections of the bronchus ( $k$ ) and parenchyma ( $n$ ) are shown with their controls (l and o), respectively. Corresponding haematoxylin and eosin sections are shown in $\mathrm{g}$ ), j), $\mathrm{m}$ ) and $\mathrm{p}$ ). Scale bar $=20 \mu \mathrm{M}$.

HMB-45 positivity was not seen in cells from control patients (fig. 1c), nor was it apparent in sections taken from bronchial segments (fig. 1k) or parenchyma (fig. 1n) from these patients.

Proliferation was no greater in LAM cells than that in cells from control patients (fig. 2). In initial experiments, the current authors examined proliferation in LAM cells derived from large, medium and small airways as determined by airway internal diameter ( $>5,3-5$ and $<3 \mathrm{~mm}$, respectively), but there was no difference in proliferation rates in these three groups so the data were combined. At days 3, 5 and 7, there was a 230$270 \%$ increase in cell number that was not significantly different from nonasthmatic cells (250-290\%). Exogenous $\mathrm{PGE}_{2}$, budesonide, fluticasone, formoterol and salmeterol all caused $\sim 40-60 \%$ inhibition of proliferation, and there was no difference in the effect in LAM cells and nonasthmatic control cells (fig. 3). Rapamycin was by far the most effective inhibitor, producing almost complete inhibition at $2 \times 10^{-9} \mathrm{M}$. Again, there was no difference between the effect of rapamycin in LAM and non-LAM cells (fig. 3).

However, $\mathrm{PGE}_{2}$ release was markedly different in LAM cells (fig. 4a). At day 1 of culture, PGE $_{2}$ levels in control cells in response to stimulation with $5 \%$ FBS were $100 \pm 51 \mathrm{ng} \cdot \mathrm{mL}^{-1} /$ $10^{6}$ cells compared with $10 \pm 2 \mathrm{ng} \cdot \mathrm{mL}^{-1} / 10^{6} \mathrm{LAM}$ cells and $24 \pm 8 \mathrm{ng} \cdot \mathrm{mL}^{-1} / 10^{6}$ asthmatic cells. The low levels of $\mathrm{PGE}_{2}$ in the LAM cells were associated with low levels of expression of COX-2 in response to stimulation with $5 \%$ FBS (fig. 5). In control cells, stimulation with 5\% FBS resulted in a significant increase in COX-2 mRNA at 2 and $6 \mathrm{~h}(\mathrm{p}<0.05, \mathrm{n}=3)$, which was not seen in LAM cells $(\mathrm{p}>0.05, \mathrm{n}=3$; fig. 5).

VEGF release, in contrast to $\mathrm{PGE}_{2}$ production, was similar in all cell types. Levels rose in response to FBS stimulation and this was maintained over the 4 days in culture (fig. $4 \mathrm{~b}$ ). 


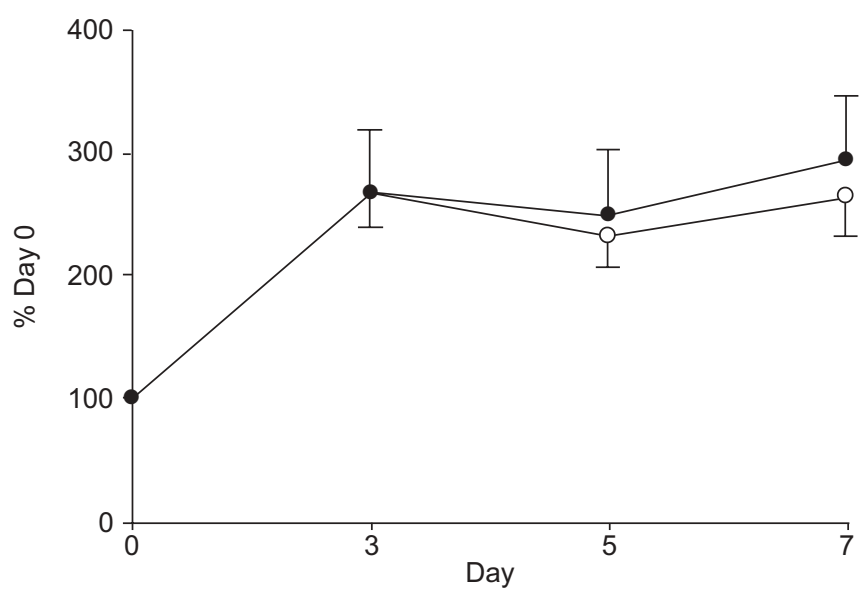

FIGURE 2. Proliferative responses to $5 \%$ foetal bovine serum in cells derived from patients with lymphangioleiomyomatosis (LAM; O; $n=6-8$ ) and non-LAM individuals $(\bullet ;=6)$. Cell numbers are expressed as a percentage of the count estimated on day 0 .

CTGF mRNA levels were, as found in previous studies [11], higher in asthmatic cells after 4 and 8 h stimulation with TGF- $\beta$ than in control cells, but CTGF expression was not increased in LAM cells (data not shown).

The effect of TGF- $\beta$ stimulation on elastin expression differed markedly in LAM cells when compared with the other two cell types. TGF- $\beta$ increased elastin mRNA in all cells from 4 to $24 \mathrm{~h}$ stimulation, but, at $24 \mathrm{~h}$, elastin levels were only $20 \%$ of that in asthmatic and control cells (fig. 6).

All ECM proteins were released from the three cell types. However, the profile of ECM proteins released from LAM cells was not different from that of asthmatic or nonasthmatic muscle (table 2).

Although all integrins studied $\left(\beta_{1}, \alpha_{1}, \alpha_{2}, \alpha v, \alpha_{4}\right.$ and $\left.\alpha_{5}\right)$ were expressed on the cells of both LAM and control patients, the level of expression did not differ for any of the integrins in the two cell types (data not shown).

\section{DISCUSSION}

In order to increase understanding of LAM, it is critical to elucidate its pathogenesis and this means identifying the characteristics of the LAM cell. The current study shows that LAM cells exhibit some abnormal behaviour in vitro. Although they did not proliferate more rapidly than control, non-LAM cells, the release of endogenous $\mathrm{PGE}_{2}$ from LAM cells was decreased, as were stimulated levels of COX-2. Expression of CTGF and release of VEGF were not different, nor was the response to a variety of antiproliferative agents, namely $\mathrm{PGE}_{2}$, corticosteroids, long-acting $\beta$-agonists and rapamycin. Elastin release in response to stimulation with TGF- $\beta$ was markedly decreased in LAM cells, although there were no qualitative or quantitative differences in a large number of ECM proteins studied, nor in the expression of integrin receptors.

Identification of the LAM cell itself is problematic. Controversy exists as to its origin, either local, from within the lung, or metastasising from a distant site. The current authors selected cells on the basis of their location within clearly defined muscle bundles and also for positive staining for $\alpha$-smooth muscle actin and, in the majority of cases, for HMB-45. However, others have found that even with the use of microdissection, muscle cells from individual LAM nodules are heterogeneous in their staining for HMB-45 and also for markers of proliferation, such as proliferating cell nuclear antigen (PCNA) [5]. The current authors were surprised that they could not demonstrate an increased proliferation for LAM cells, as they have previously reported this for cells derived from patients with asthma [10, 13], especially since LAM is described as a disease in which the LAM cell is hyperproliferative. GONCHAROVA et al. [4] showed, using bromodeoxyuridine, that basal DNA synthesis was increased in cells from two LAM patients and that the p70S6 kinase and S6 kinase pathways were overactivated in LAM cells. However, they did not report any differences in the cells' response to mitogenic stimulation. Again, the findings of the current study may reflect the phenotypic diversity of the LAM cells studied and that there may be an inverse correlation between staining for HMB-45 and PCNA. The fact that HMB-45 positivity was noted may indicate that cells were selected that were not hyperproliferative [5].

In the current study, the in vitro properties of LAM-derived cells were compared with those obtained from patients diagnosed with a variety of other conditions, including primary pulmonary hypertension, carcinoma and tetralogy of Fallot. The current authors acknowledge that these controls are not strictly normal, i.e. disease free. However, cells from two patients in this group were cultured from lung tissue from potential transplant donors whose lungs were not suitable for transplantation, for reasons other than the presence of pulmonary disease. The responses of the cells from these two patients did not exhibit major differences from those of the rest of the control group. Nevertheless, these numbers are small and the possibility that the presence of non-LAM nonasthma pulmonary disease could have influenced the results cannot be discounted.

Interestingly, the current authors found that LAM cells released lower levels of endogenous $\mathrm{PGE}_{2}$ than control cells, but similar levels to those released by asthma-derived cells. Since it was shown in the present study that $\mathrm{PGE}_{2}$ inhibits proliferation of LAM-derived cells, there is a potential for a hyperproliferative state in vivo if endogenous $\mathrm{PGE}_{2}$ levels are low. The current authors have previously reported that low levels of endogenous $\mathrm{PGE}_{2}$ in ASM cells derived from asthma patients are associated with decreased expression of COX-2 [12]. In the current study, the authors found a similar abnormality in the LAM cells, in that stimulation failed to upregulate COX-2. It is unlikely that this reflects a general dysregulation of cell function, since the response of the LAM cells to proliferative and profibrotic stimuli, such as TGF- $\beta$, was not abnormal. The mechanism of the failure of stimulation to upregulate COX-2 remains unknown and requires further study.

There has recently been some challenge to the idea that LAM is a disease of the smooth muscle cell, supported by data demonstrating specific changes in the ECM instead. MERRILEES et al. [15] reported that LAM lung contained twice 

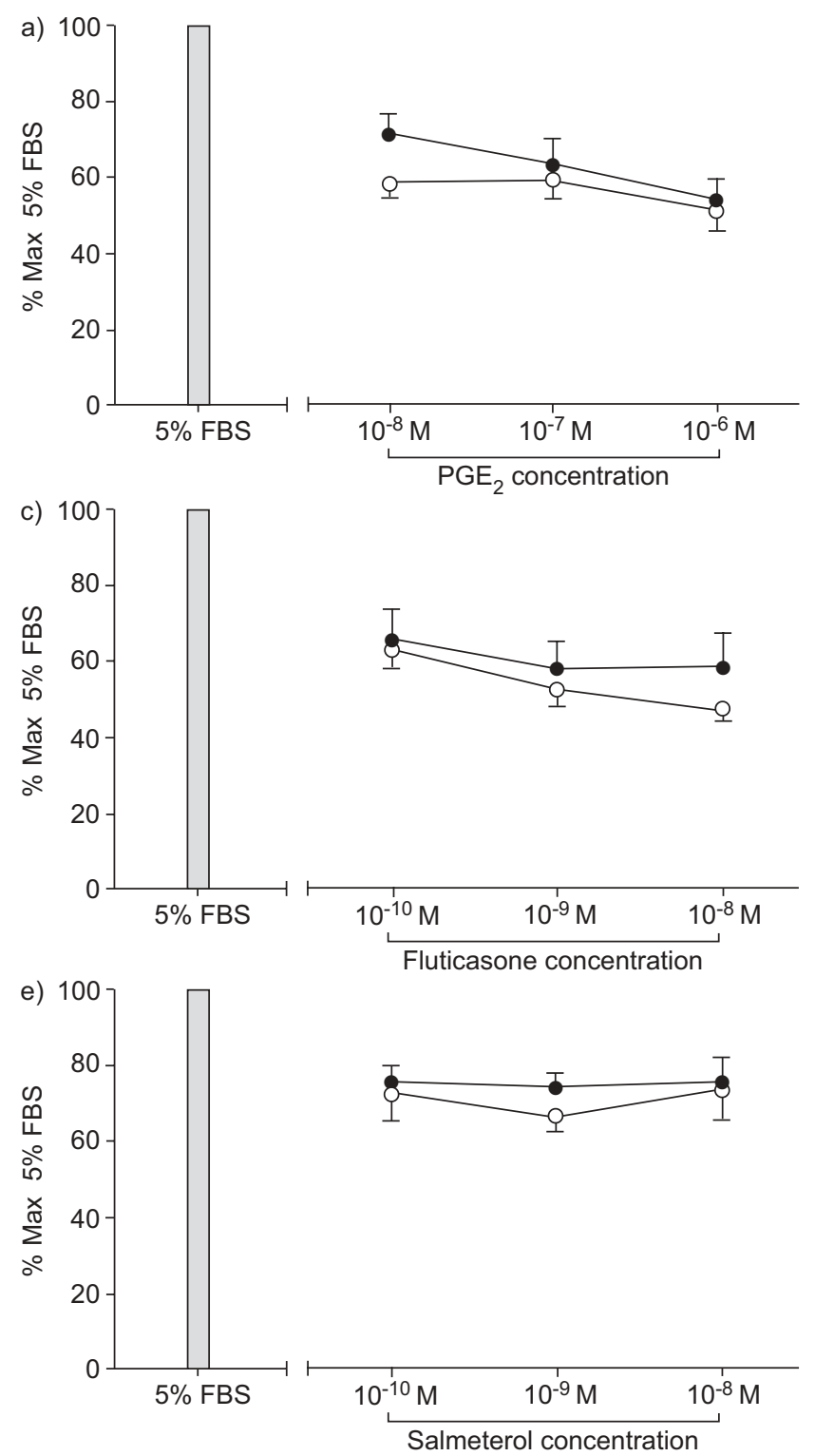

b)

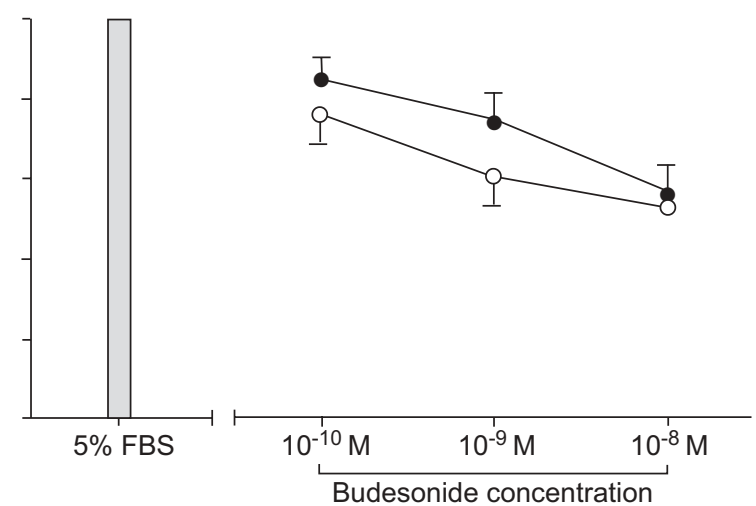

d)

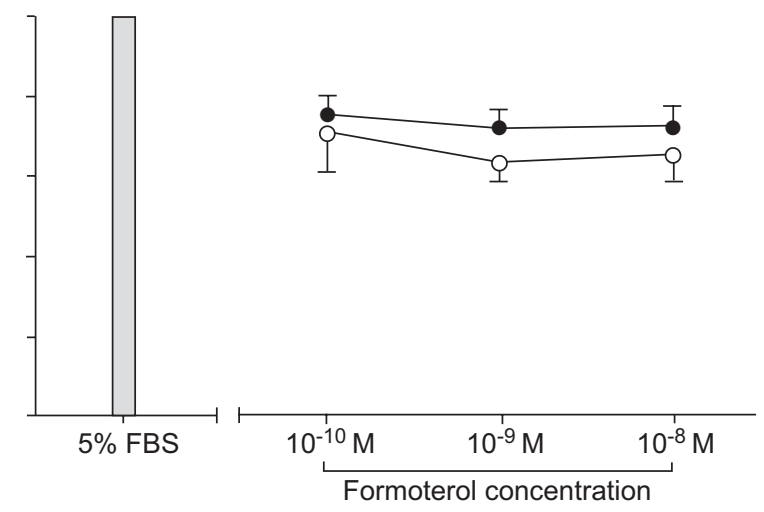

f)

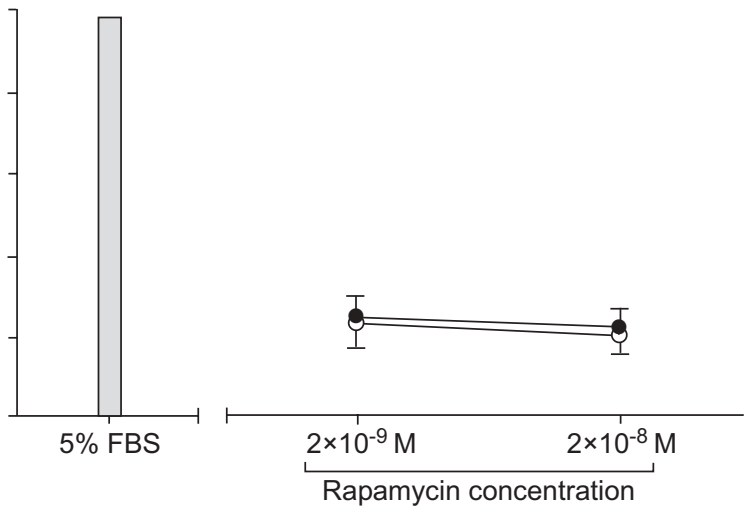

FIGURE 3. Effect of inhibitors of proliferation on lymphangioleiomyomatosis (LAM) derived $(O ; n=4)$ and non-LAM derived $(\bullet ; n=5)$ smooth muscle cells. Results are expressed as a percentage of ${ }^{3} \mathrm{H}$-thymidine counts in the presence of $5 \%$ foetal bovine serum (FBS). Max: maximum; $P G E_{2}$ : prostaglandin $E_{2}$.

as much interstitial tissue as the control lung, with smooth muscle cells accounting for $<25 \%$ of interstitial $v / f$. Areas of interstitial tissue stained strongly for the matrix proteoglycans versican and biglycan. Decorin was prominent in association with collagen bundles. Smooth muscle cells did not stain, or stained lightly, for proteoglycans. Versican deposits were closely associated with interstitial fibroblasts. Interstitial regions contained significant amounts of elastin $(\sim 13 \% \mathrm{v} / \mathrm{f})$, but with fibres in disorganised patterns. Elastic fibres were absent from areas that stained strongly for versican and biglycan. These areas showed weak staining for elastin binding protein (EBP), consistent with proteoglycan-induced shedding of EBP and inhibition of elastic fibre formation. These findings point to a significant contribution from matrix proteoglycans to the expanded and remodelled lung tissue of LAM patients. The current authors' results from experiments examining the matrix proteins secreted from LAM cells are inconsistent with these findings, except for the fact that they observed diminished levels of elastin expression. Whether the versican or biglycan levels were raised is not known. However, ECM proteins are secreted by many cells other than muscle and this may account for the differences.

The reason for the selective lack of upregulation of elastin mRNA by TGF- $\beta$ in LAM-derived cells is not apparent. In human lung foetal fibroblasts, this upregulation occurs at the post-transcriptional level through stabilisation of mRNA. The signalling pathways involved in these events include Smads, phospholipase $C$, protein kinase $C-\delta$ and p38, as well as synthesis of new protein [16]. Whether this is also true for ASM cells, and at which point in the pathways the abnormality observed in LAM cells occurs, needs further study. 

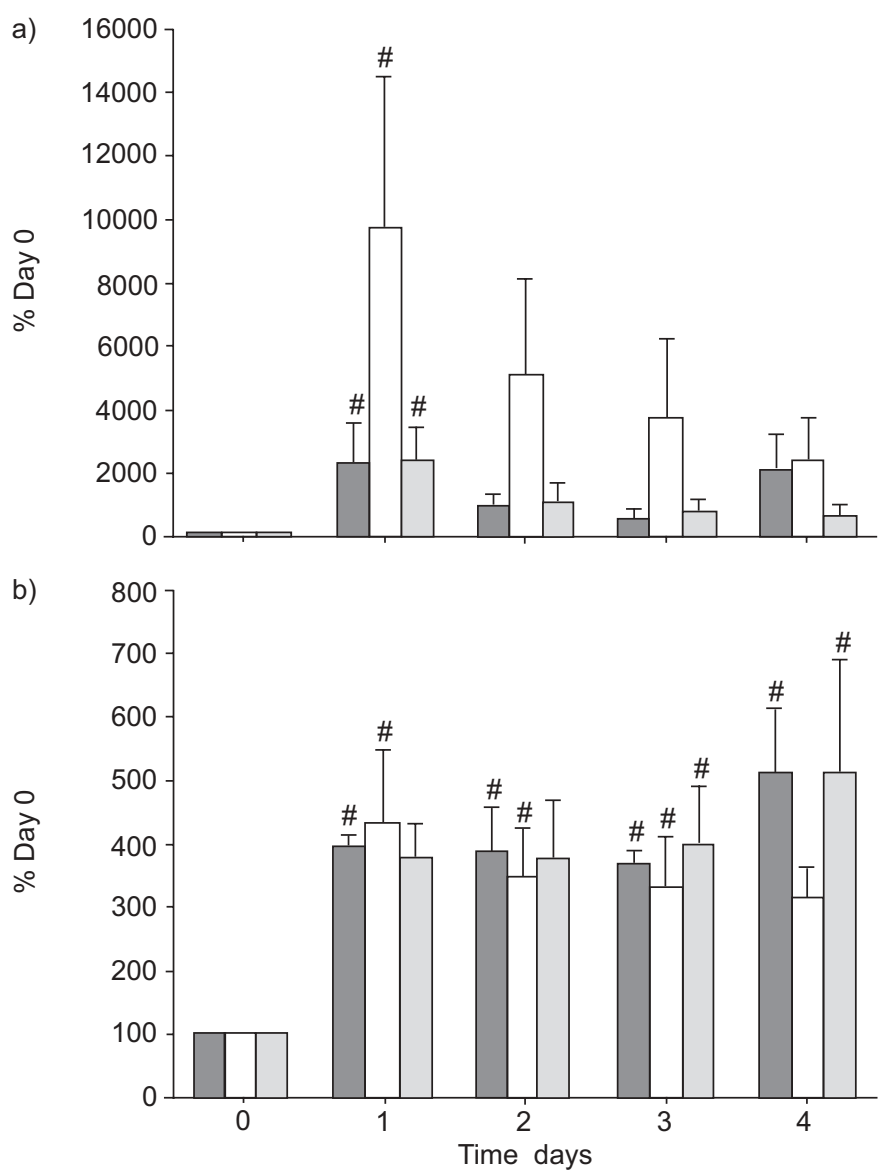

FIGURE 4. Release of prostaglandin $E_{2}$ (a) and vascular endothelial growth factor (VEGF; b) from lymphangioleiomyomatosis (LAM; $\square$ ), asthmatic ( $\square$ ) and non-LAM, control cells $(\square)$ in response to $5 \%$ foetal bovine serum over 4 days in culture. Results are presented as mean \pm SEM $(n=4-5$ asthmatic, $6-8$ nonasthmatic and 5-6 LAM). ${ }^{*}: p \leqslant 0.05$.

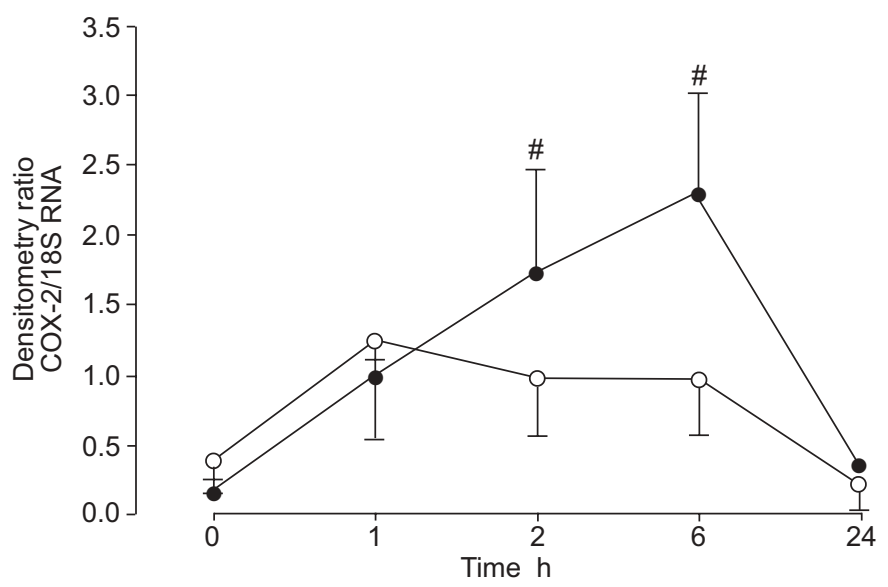

FIGURE 5. Cyclooxygenase-2 (COX-2) mRNA expression in lymphangioleiomyomatosis (LAM; $\bigcirc)$ and non-LAM $(\bullet)$ cells in response to stimulation with $5 \%$ foetal bovine serum. Upregulation of COX-2 mRNA occurred only in nonLAM cells. Data are presented as mean $\pm \operatorname{SEM}(n=3) .{ }^{*}$ : significant difference from $0 \mathrm{~h}$.

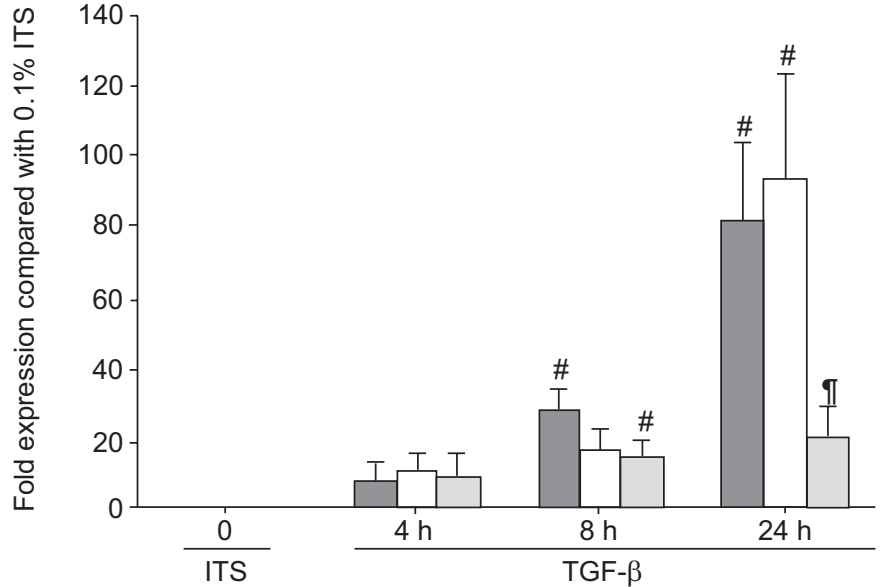

FIGURE 6. Elastin expression in asthmatic (Ш), lymphangioleiomyomatosis $(L A M ; \square)$ and non-LAM, control $(\square)$ cells in response to stimulation with transforming growth factor (TGF)- $\beta\left(1 \mathrm{ng} \cdot \mathrm{mL}^{-1}\right)$. Data are presented as mean $\pm \operatorname{SEM}(\mathrm{n}=6)$. * : significant difference from $0 \mathrm{~h}$ insulin, transferrin, selenium (ITS); ๆ: significant difference from asthmatic cells $(p<0.03)$.

\section{TABLE 2 Extracellular matrix protein data}

\begin{tabular}{lccc} 
Protein & LAM & Asthma & Control \\
\hline Subjects n & 7 & 6 & 7 \\
Fibronectin & $1.2 \pm 0.3$ & $1.1 \pm 0.2$ & $0.9 \pm 0.2$ \\
Chrondroitin & $0.9 \pm 0.1$ & $0.7 \pm 0.1$ & $0.8 \pm 0.1$ \\
$\quad$ sulphate & & & \\
Thrombospondin & $0.4 \pm 0.1$ & $0.5 \pm 0.2$ & $0.4 \pm 0.2$ \\
Perlecan & $0.7 \pm 0.3$ & $0.5 \pm 0.2$ & $0.6 \pm 0.3$ \\
Elastin & $0.7 \pm 0.2$ & $0.4 \pm 0.04$ & $0.6 \pm 0.1$ \\
Versican & $1.0 \pm 0.1$ & $0.8 \pm 0.1$ & $0.9 \pm 0.1$ \\
Collagen I & $0.7 \pm 0.1$ & $0.6 \pm 0.1$ & $0.7 \pm 0.1$ \\
Collagen IV & $0.3 \pm 0.1$ & $0.2 \pm 0.02$ & $0.3 \pm 0.04$ \\
\hline
\end{tabular}

Data are presented as mean \pm SE for optical density units with values for cells alone and isotype control subtracted. Results have been normalised for cell number. LAM: lymphangioleiomyomatosis.

This is the first study to report release of VEGF from LAMderived cells, although it has been previously reported that ASM cells release VEGF [17]. The current authors had expected that, given the involvement of blood vessels in LAM and the frequent occurrence of haemoptysis, they would observe some increase in VEGF release from the LAM cells. However, the remodelling associated with asthma also involves angiogenesis and yet levels of VEGF produced from asthma-derived cells were also no greater than those from control cells. It is possible that any differences lie in the downstream effects of the released VEGF, as opposed to the levels released.

In summary, lymphangioleiomyomatosis-derived muscle cells were found to exhibit abnormal properties in vitro, which are sustained in culture. The contribution of these properties to the pathophysiology and symptomatology of lymphangioleiomyomatosis requires further study. 


\section{REFERENCES}

1 Johnson SR, Whale CI, Hubbard RB, Lewis SA, Tattersfield AE. Survival and disease progression in UK patients with lymphangioleiomyomatosis. Thorax 2004; 59: 800-803.

2 McCormack F, Brody A, Meyer C, et al. Pulmonary cysts consistent with lymphangioleiomyomatosis are common in women with tuberous sclerosis: genetic and radiographic analysis. Chest 2002; 1213: Suppl. 3, 61 S.

$3 \mathrm{Yu} \mathrm{J}$, Astrinidis A, Henske EP. Chromosome 16 loss of heterozygosity in tuberous sclerosis and sporadic lymphangiomyomatosis. Am J Respir Crit Care Med 2001; 164: 1537-1540.

4 Goncharova EA, Goncharor DA, Eszterhas A, et al. Tuberin regulates p70 S6 kinase activation and ribosomal protein $\mathrm{S} 6$ phosphorylation. A role for the TSC2 tumor suppressor gene in pulmonary lymphangioleiomyomatosis (LAM). J Biol Chem 2002; 277: 30958-30967.

5 Matsumoto Y, Horiba K, Usuki J, Chu SC, Ferrans VJ, Moss J. Markers of cell proliferation and expression of melanosomal antigen in lymphangioleiomyomatosis. Am J Respir Cell Mol Biol 1999; 21: 327-336.

6 Inoue Y, King TE Jr, Barker E, Daniloff E, Newman LS. Basic fibroblast growth factor and its receptors in idiopathic pulmonary fibrosis and lymphangioleiomyomatosis. Am J Respir Crit Care Med 2002; 166: 765-773.

7 Evans SE, Colby TV, Ryu JH, Limper AH. Transforming growth factor-beta 1 and extracellular matrix-associated fibronectin expression in pulmonary lymphangioleiomyomatosis. Chest 2004; 125: 1063-1070.

$8 \mathrm{Yu} \mathrm{J}$, Astrinidis A, Howard S, Petri Henske E. Estradiol and tamoxifen stimulate LAM-associated angiomyolipoma cell growth and activate both genomic and nongenomic signaling pathways. Am J Physiol Lung Cell Mol Physiol 2004; 286: L694-L700.
9 Hayashi T, Fleming MV, Stetler-Stevenson WG, et al. Immunohistochemical study of matrix metalloproteinases (MMPs) and their tissue inhibitors (TIMPs) in pulmonary lymphangioleiomyomatosis (LAM). Hum Pathol 1997; 28: 1071-1078.

10 Johnson PR, Roth M, Tamm M, et al. Airway smooth muscle cell proliferation is increased in asthma. Am J Respir Crit Care Med 2001; 164: 474-477.

11 Burgess JK, Johnson PR, Ge Q, et al. Expression of connective tissue growth factor in asthmatic airway smooth muscle cells. Am J Respir Crit Care Med 2003; 167: 71-77.

12 Chambers LS, Black JL, Ge Q, et al. PAR-2 activation, PGE2, and COX-2 in human asthmatic and nonasthmatic airway smooth muscle cells. Am J Physiol Lung Cell Mol Physiol 2003; 285: L619-L627.

13 Roth $\mathrm{M}$, Johnson PR, Borger $\mathrm{P}$, et al. Dysfunctional interaction of $\mathrm{C} / \mathrm{EBPalpha}$ and the glucocorticoid receptor in asthmatic bronchial smooth-muscle cells. $N$ Engl J Med 2004; 351: 560-574.

14 Johnson PR, Burgess JK, Underwood PA, et al. Extracellular matrix proteins modulate asthmatic airway smooth muscle cell proliferation via an autocrine mechanism. J Allergy Clin Immunol 2004; 113: 690-696.

15 Merrilees MJ, Hankin EJ, Black JL, Beaumont B. Matrix proteoglycans and remodelling of interstitial lung tissue in lymphangioleiomyomatosis. J Pathol 2004; 203: 653-660.

16 Kucich U, Rosenbloom JC, Abrams WR, Rosenbloom J. Transforming growth factor- $\beta$ stabilizes elastin mRNA by a pathway requiring active smads, protein kinase $\mathrm{C}-\delta$ and p38. Am J Respir Cell Mol Biol 2002; 26: 183-218.

17 Knox AJ, Corbett L, Stocks J, Zhu YM, Pang L. Human airway smooth muscle cells secrete vascular endothelial growth factor: up-regulation by bradykinin via a protein kinase $\mathrm{C}$ and prostanoid-dependent mechanism. FASEB J 2001; 15: 2480-2488. 